\title{
Historical perspectives of The American Association for Thoracic Surgery: Herbert Sloan
}

\author{
Cameron D. Wright, MD
}

Herbert Sloan, the 60th president of The American Association for Thoracic Surgery (AATS), was born on October 10, 1914, in Clarksburg, WV, the sixth of the 7 children of Luella Dye and Dr Herbert E. Sloan, also a surgeon. He earned an $\mathrm{AB}$ degree from Washington and Lee University in 1936, where he was a varsity wrestler. He graduated summa cum laude and was elected to Phi Beta Kappa. He received his medical degree from the Johns Hopkins University in 1940 and was elected to Alpha Omega Alpha. Dr Sloan stayed on at Hopkins and spent a war-shortened 4 more years there, rising to the resident surgeon level. He recalled the World War II years when he was a second-year house officer in a reflection in 2002:

"All of the older residents who had been around forever and were practically professors - it was like that at Hopkins - went off to the war and left a bunch of young, inexperienced jerks to try to handle things. That was the most challenging time of my whole life. Every bit of my ability I had was being used to the utmost. That's the way I felt during those years when us punks were trying to do things that real men did." 1

On May 3, 1943, Dr Sloan married Doris Edwards, a surgical nurse who had graduated at the top of the Hopkins School of Nursing class of 1940 (Figure 1). Dr Sloan's surgical training was interrupted by the war, and he served in the army and rose to the rank of major. He was stationed on Okinawa, Japan, and in Korea from 1944 to 1947. He was the chief of surgery of the $34^{\text {th }}$ General Hospital in Seoul, South Korea. It was on Okinawa that his interest in thoracic surgery was stimulated by J. Maxwell Chamberlain, who convinced him to arrange a thoracic surgery residency at the conclusion of his military commitment. With Dr Chamberlain's support, Sloan secured a thoracic residency position at the University of Michigan under Dr John Alexander (17th AATS president) and Dr Cameron Haight (36th AATS president) (Figure 2). A letter written

From the Division of Thoracic Surgery, Massachusetts General Hospital, Boston, Mass.

Disclosures: Author has nothing to disclose with regard to commercial support.

Received for publication March 17, 2013; accepted for publication April 2, 2013; available ahead of print April 9, 2013

Address for reprints: Cameron D. Wright, MD, Division of Thoracic Surgery, Massachusetts General Hospital, Blake 1570, 55 Fruit St, Boston, MA 02114

(E-mail: wright.cameron@mgh.harvard.edu).

J Thorac Cardiovasc Surg 2013;145:1428-30

0022-5223/\$36.00

Copyright (c) 2013 by The American Association for Thoracic Surgery

http://dx.doi.org/10.1016/j.jtcvs.2013.04.001 by J. Maxwell Chamberlain to John Alexander, dated March 27, 1947, includes this opinion of Sloan:

"I believe Herb will be one of the most outstanding you have trained. He stands knowingly well, and will be appreciated most later, since he is not the flashy type in the beginning. Very honest, very modest." 2

Dr Sloan joined the faculty of the University of Michigan in 1949. He spent his entire career at the university, attaining the rank of professor in 1962 and becoming the head of the Section of Thoracic Surgery in 1970, until his retirement in 1985 . His service to his patients and the university were recognized by the inauguration of the Herbert Sloan Professorship on May 6, 2004 (Figure 3). He was one of the leaders in the new field of cardiac surgery and performed the first open-heart operation in Michigan. He was renowned for his technical skill and superb judgment in the operating room. He demanded excellence from himself and would not tolerate mediocrity in others. Dr Sloan trained 49 residents while he was the head of the section, 12 of whom became division or department chairs. Dr Marvin Kirsh, one of his residents and later colleague, reported:

"He was not one to hand out compliments. We knew we had performed well, however, when he would look us in the eye and say, "that operation was well done.",3

Dr Sloan was active nationally and led many important thoracic surgical efforts. He was editor of the Annals of Thoracic Surgery from 1969 to 1984, until he transferred the reins to Dr Thomas B. Ferguson (62nd AATS president). Sloan reflected on the troubles of a journal editor in 1989 that remain true today:

\footnotetext{
"Reviewers are a chancy lot. Two reviewers of equal stature, each well respected in the field, often returned diametrically opposed evaluations of the same manuscript. The editor frequently found himself adjudicating these differences of opinion. Review promptness became a holy grail., 4
}

Dr Sloan served many roles for the American Board of Thoracic Surgery during his 20-year involvement from 1966 to 1986 , longer than any other surgeon. He was devoted to the Board and its mission and wrote a detailed history of the Board with wonderful pictures and historical notes that was published in $1998 .{ }^{5}$ Dr Sloan was elected the 10th president of the Society of Thoracic Surgeons in 1974, one of only a handful to become president of both 


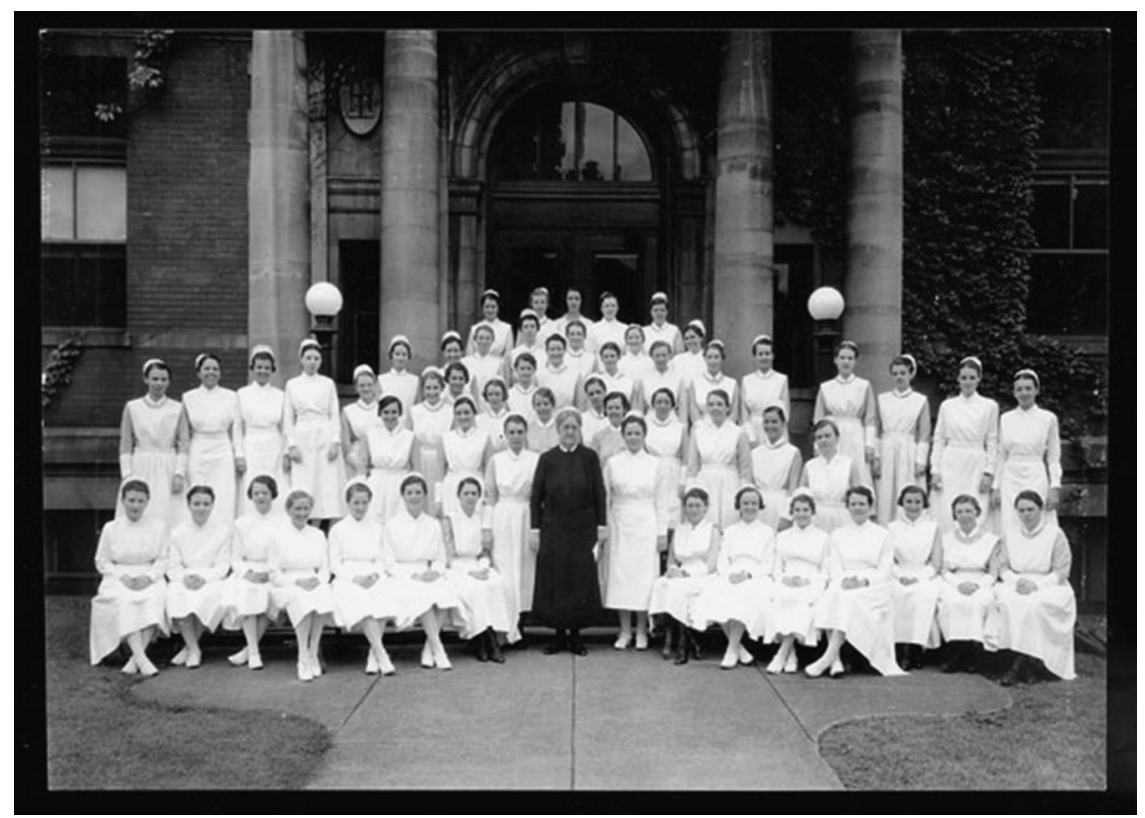

FIGURE 1. The Johns Hopkins School of Nursing graduating class, 1940. Doris Edwards (the class valedictorian) is seated in the first row just to the right of Miss Lawler (as we look at the picture), the standing woman in black who was the director of the nursing school.

major US thoracic surgical groups. His 1975 Presidential Address, entitled "The Breeding and Feeding of Thoracic Surgeons," focused on 3 concepts he believed were important to strengthen thoracic surgery: (1) better cooperation between the American Board of Thoracic Surgery, the Residency Review Committee, and program directors; (2) matching the supply of thoracic surgeons to the needs of the country; and (3) the importance of ongoing evaluation of clinical competence. ${ }^{6}$

Dr Sloan was elected president of the AATS in 1979 and delivered his Presidential Address in San Francisco, Calif, on April 30, 1980, entitled "Let Us Now Praise Famous
Men."7 He quoted a poem by Rudyard Kipling, entitled "A School Song":

"Let us now praise famous men"-

Men of little showing-

For their work continueth,

And their work continueth,

Greater than their knowing!

The spirit of his address was the importance of the American Board of Thoracic Surgery and the surgeons who served

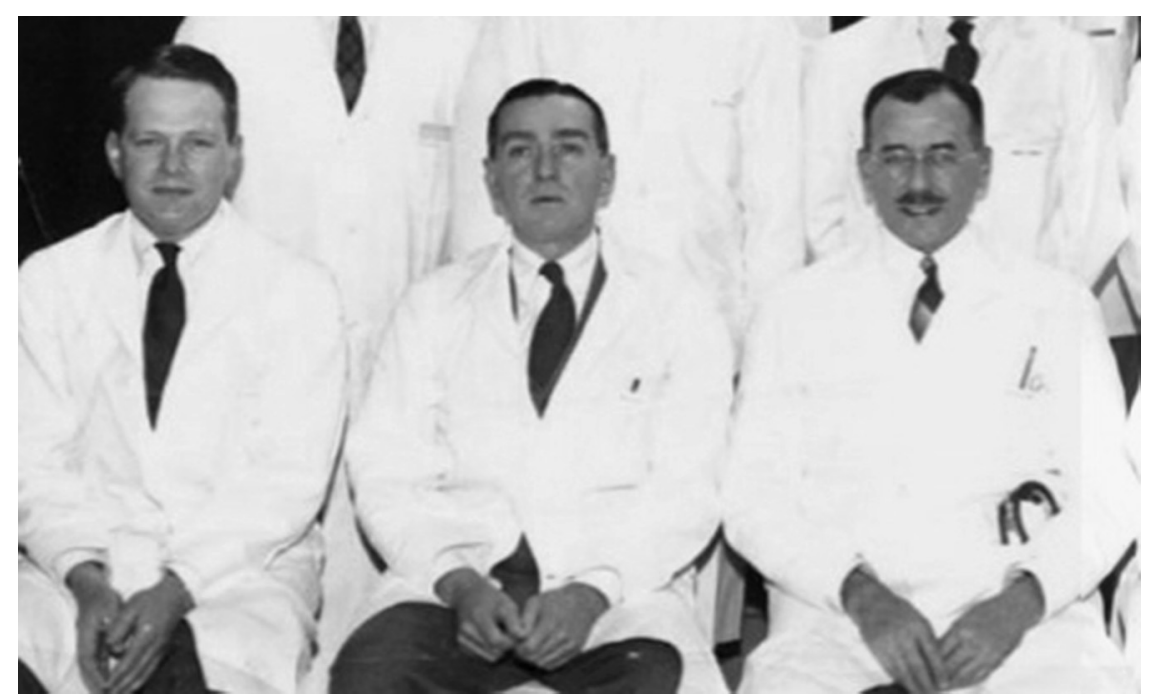

FIGURE 2. Herbert Sloan (left), Cameron Haight (middle), and John Alexander (right) at the University of Michigan, 1947. 


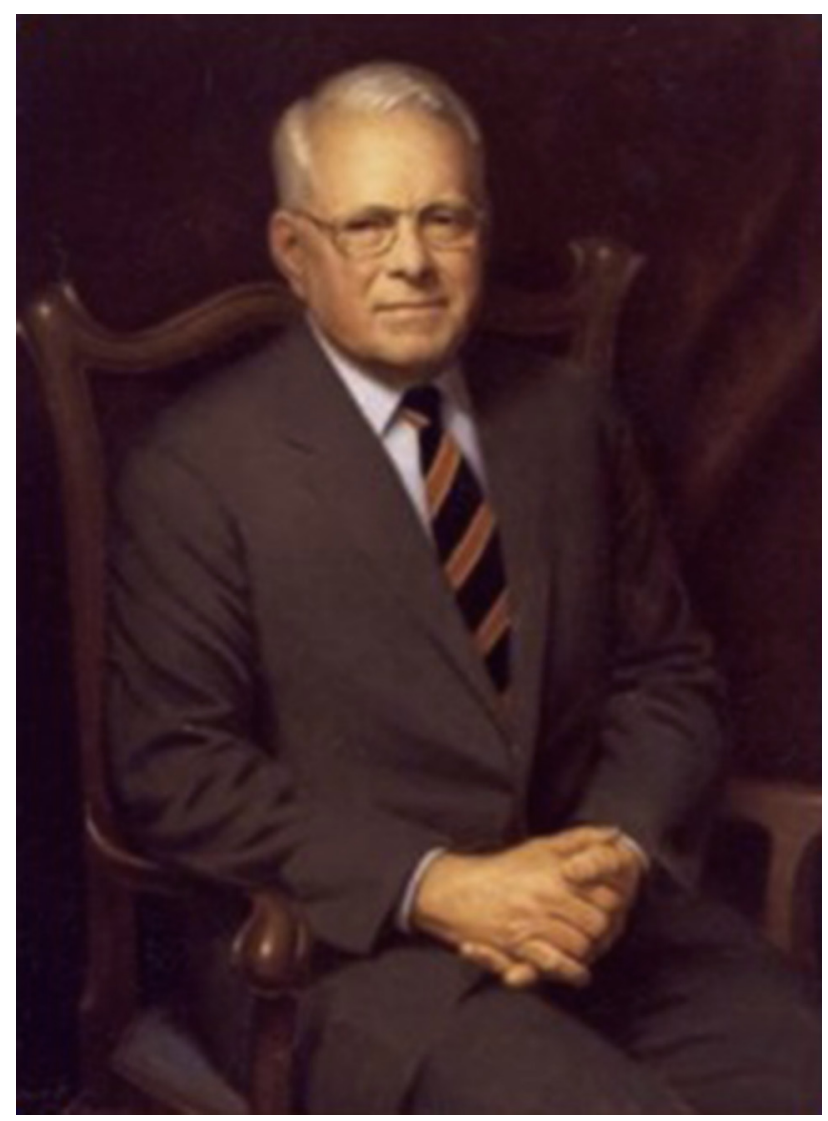

FIGURE 3. Portrait of Herbert Sloan, MD.

its mission. He traced the history of the Board from its founding, emphasizing the importance of the AATS members in bringing the Board to fruition. His opening remarks are quintessential Sloan in self-deprecation:

"Preceded by the world's finest cardiac surgeon (John Kirklin) and to be succeeded by a surgeon equally renowned in the area of general thoracic surgery (Donald Paulson), it did not seem appropriate for me to present material of a scientific nature."

Herbert and Doris Sloan raised 5 children (Elizabeth Smith, Herbert Sloan III, Robert Sloan, John Sloan, and Ann Devlin) and have always resided in Ann Arbor, Mich, retiring from all university activities in 1987, with his appointed to Emeritus Professor of Surgery. Dr Sloan was a passionate flower gardener with a special interest in

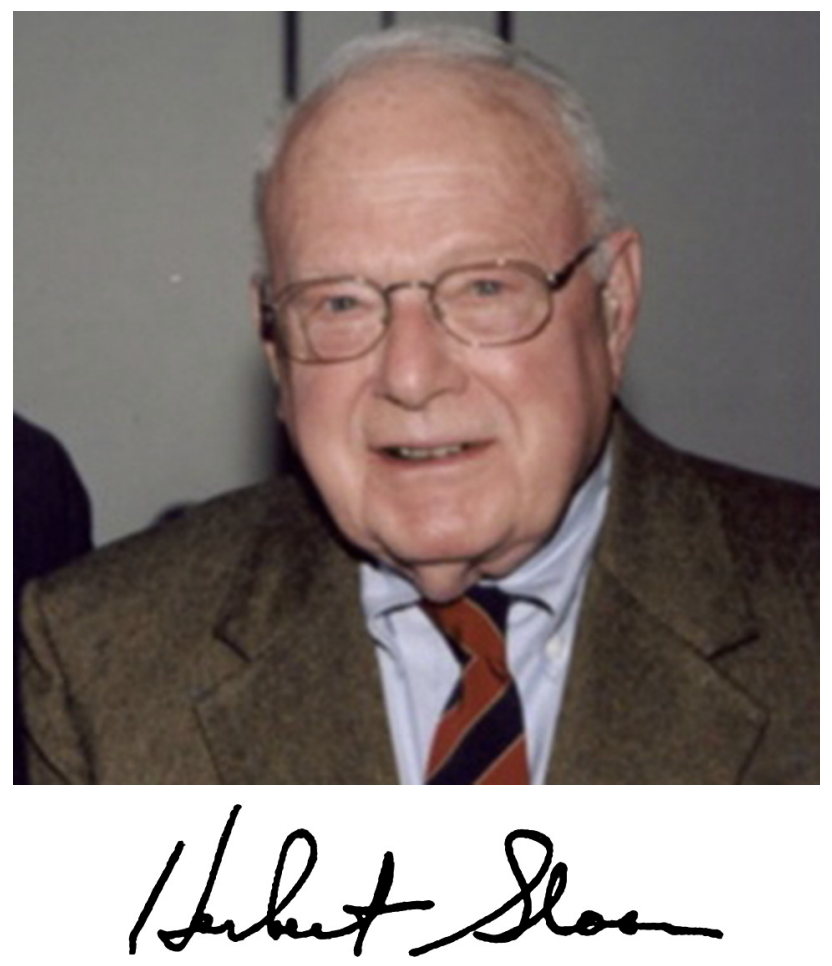

FIGURE 4. Top, Herbert Sloan, MD, at the John Alexander Society meeting in 2005. Bottom, Signature of Herbert Sloan.

rhododendrons. He also enjoyed photography and traveling and was the president of the Ann Arbor Figure Skating Club. Dr Sloan's beloved wife, Doris, died in 1989. Dr and Mrs Sloan were devoted to their alma mater, Johns Hopkins, funding the Doris Edwards Sloan Room in the School of Nursing and an endowed scholarship to the Medical School. Dr Sloan still resides in Ann Arbor, now in his 100th year (Figure 4).

\section{References}

1. Hill W. The residency years, then and now. Medicine at Michigan. Winter 2002;4: 46-51.

2. Chamberlain JM. Letter from March 27, 1947, to John Alexander (unpublished).

3. Kirsh MM. Herbert Sloan, MD: a consummate surgeon. Ann Thorac Surg. 1984; 58:99.

4. Sloan H. More change. Ann Thorac Surg. 1989;47:6-7.

5. Sloan H. The American Board of Thoracic Surgery: A 50 Year Perspective. Evanston, IL: The American Board of Thoracic Surgery; 1998.

6. Sloan H. The breeding and feeding of thoracic surgeons. Ann Thorac Surg. 1975; 20:371-86

7. Sloan H. Let us now praise famous men. J Thorac Cardiovasc Surg. 1980;80: 159-70. 